\title{
Soil Diversity and Land Use in the United States
}

\author{
Ronald Amundson, ${ }^{*}$ Y. Guo, ${ }^{1}$ and P. Gong ${ }^{1,2,3}$ \\ ${ }^{1}$ Division of Ecosystem Sciences, 151 Hilgard Hall, University of California, Berkeley, California 94720-3110, USA; ${ }^{2}$ Center for \\ Assessment and Monitoring of Forest and Environmental Resources (CAMFER), University of California, Berkeley, California \\ 94720-3110, USA; ${ }^{3}$ International Institute for Earth System Science (ESSI), Nanjing University, China, 210093
}

\begin{abstract}
Soils are dynamic components of terrestrial ecosystems that historically have been viewed as economic resources by government and private interests. The large-scale conversion of many sections of the United States to agriculture and urban land uses, combined with the growing awareness of the role of soils in global biogeochemistry and ecology, ultimately requires an assessment of the remaining distribution of undisturbed soils in the country. Here we conduct the first quantitative analysis of disturbed and undisturbed soil distribution in the USA using a GIS-based approach. We find that a sizable fraction $(4.5 \%)$ of the nation's soils are in danger of substantial loss, or complete extinction,
\end{abstract}

"A town is saved, not more by the righteous men in it than by the woods and swamps that surround it."H. D. Thoreau (2001)

\section{INTRODUCTION}

Concern over the fate of terrestrial biotic diversity in the face of increasing human domination of the planet (Vitousek and others 1997a) has focused mainly on the aboveground flora and fauna. Yet soils, the foundation of terrestrial ecosystems (Yaalon 2000), are rarely explicitly considered in these discussions. Soils are biogeochemically dynamic bodies, formed by the combined effects of environmental and biological factors over (commonly) geological expanses of time (Amundson and Jenny 1997). The combina-

Received 14 March 2002; accepted 11 October 2002; published online June 19, 2003.

*Corresponding author; e-mail: earthy@nature.berkeley.edu due to agriculture and urbanization. In the agricultural belt of the country, up to $80 \%$ of the soils that were naturally of low abundance are now severely impacted (greater than 50\% conversion to agricultural/urban uses). Undisturbed soils provide ecosystem services that warrant their preservation, including a somewhat complex relationship with rare or endangered plants. The known and unknown attributes of undisturbed soils suggests the need for an integrated biogeodiversity perspective in landscape preservation efforts.

Key words: soils; biological diversity; land use; extinction. tion of oscillating glacial/interglacial climates and unique floras and faunas which have controlled soil formation during the Quaternary period is unique in Earth's history, which suggests that exact analogs of present soils have not existed in the past nor will they form again in the future. For these reasons and more, it seems prudent that undisturbed soils-and their values and services-be given careful consideration in the development of bio- and geodiversity planning (Amundson 1998, 2000; Ibáñez and others 1995).

Here we present the first quantitative analysis of the human impact upon soil diversity for the US. We then discuss the significance of these findings and the importance of maintaining natural soil diversity. We used a Geographical Information Systems (GIS)-based approach to the problem, combining digital data on soil distribution and land use in the US. The results reveal both the nation's original soil geography and the patterns of heavily impacted soils in the US, providing a basis for identi- 
Table 1. Brief Description of the Characteristics of the Soil Orders Found in the STATSGO Database

\begin{tabular}{ll}
\hline Order & Characteristics \\
\hline Alfisols & Clay-enriched B horizons with base saturation greater than $35 \%$ \\
Andisols & Formed from volcanic parent materials with unique chemical properties \\
Aridsols & Soils with observable weathering/chemical alteration in arid climates \\
Entisols & Soils lacking visible horizon development \\
Histosols & Composed primarily of organic materials \\
Inceptisols & Soils possessing some development not characteristic of other classes \\
Mollisols & Significant organic C accumulation and base saturation greater than 50\% \\
Oxisols & Highly chemically altered soils of tropics \\
Spodosols & Coarse-textured soils of northern latitude forests bearing distinctive geochemical \\
& separation of Fe and Al compounds \\
Ultisols & Clay-enriched B horizons with base saturation greater than $35 \%$ \\
Vertisols & High concentrations of silicate clay exhibiting shrink-swell behavior \\
\hline
\end{tabular}

fying target areas for biogeodiversity preservation in this country.

\section{METHODS}

\section{Definition of Soil Diversity}

Soil is a continuum (Jenny 1941), having properties that vary enormously-and continuously-with depth and with horizontal distance. For both the purposes of scientific study and land management applications, it has been a practice to classify soils by breaking the continuum into discrete units of similar properties. Here, soil diversity is quantified within the framework of the USDA Soil Taxonomy (Soil Survey Staff 1999), an international system of soil classification. The system was designed to separate soils on the basis of properties important to potential land use. As such, the system differs from scientific taxonomies where genetic linkages between objects are emphasized. The system contains five hierarchical levels that proceed from the most generalized (the soil "order") to most specific (the soil "family"). In the US, a final and more detailed extra taxonomic level is referred to as the soil "series." Any soil mapped in the US is usually given a series name and a taxonomic designation in all higher levels of the taxonomy. In comparison to biological taxonomy, the levels of the soil classification system might be viewed as proceeding from the "kingdom" (order) through "species" (series). The major distinguishing attributes of the soil orders are given in Table 1. While soils (nonreplicating entities), and the soil classification system (practical, not scientific), differ from biological entities, this analogy is at least an organizing concept on which to begin this investigation.

Recently, Ibáñez and others $(1995,1998)$ have reviewed the concepts and definitions of soil diversity, exploring the possible application of biological diversity models to soil databases. Here, we use two simple numerical parameters to quantify US soil diversity: (1) "series density": number of series/area by state, and (2) "series abundance": total area of each soil series in a state. With respect to abundance criteria, we defined the following categories of rare or uncommon soil series: (a) rare soils-less than 1,000 ha total area in US, (b) unique soils (for example, "endemic") — exist only in one state, and (c) rare-unique soils-occur only in one state, total area less than 10,000 ha. Finally, for those naturally rare soil series, we defined (d) endangered soils as those rare or rare-unique soil series that have lost more than $50 \%$ of their area to various land disturbances described below. The quantitative definition of these three classes is our first approximation for evaluating soil distribution, and as yet there is no accepted standard for defining soil rarity in the literature. Our analysis is focused on soil diversity by political boundary as opposed to ecosystem boundaries. We do this for several reasons. First, analyses of endangered plant and animal distributions are frequently made along political boundaries (Dobson and others 1997). Second, there are advantages to potential conservation planning, and public perception, when analyses are conducted by political boundary. Certainly, future analyses might also examine land use effects on soil diversity by ecosystem boundaries, such as the "Major Land Resource Area" which is embedded in the STATSGO soil database.

The criteria chosen for our definitions are first attempts to partition soils into categories deserving of attention, but, as we illustrate below, they appear to capture important features of land use effects on 
natural ecosystems. Our criteria for "endangered soils" could also be extended to all soils regardless of their original abundance.

\section{GIS Data Acquisition and Use}

The calculated area of each soil type in the State Soil Geographic Data Base (STATSGO) (1:250,000, compiled by the US National Resource Conservation Service; http:/www.ftw.usda.gov/stat_data.html) was used to calculate the area of soil types. The minimum map unit in STATSGO is $6.25 \mathrm{~km}^{2}$, equivalent to square cells of $2.5 \mathrm{~km}$ size. There are 1-21 components (components are based on soil type, landscape characteristics, and other parameters) in each map unit, and the location of each component is not known. We summarized the component percentage and area (component percentage $\times$ polygon area) of soils at the different soil classification levels (order, suborder, great group, subgroup, family, series) in each map unit identifier (MUID). Finally, the area of soil in each MUID and in each state was tabulated to obtain the total area of the soil type in the US.

Soil disturbance in the US was determined using the National Land Cover Data (NLCD, 30 m resolution), interpreted from Landsat Thematic Mapper data acquired in the early 1990s as compiled by the USGS and EPA (http://mac.usgs.gov/mac/isb/pubs/ factsheets/fs 10800.html), to extract urban (low intensity, high intensity residential, commercial/industrial/transportation, and urban recreational grasses) and agricultural lands (orchards/vineyards/ non-natural woody, row crops, small grains, and fallow). The absence of a long-time series of these satellite data neglects or misclassifies lands that have revegetated from a previous agricultural use, which makes our assessment of land use conservative. Finally, we overlaid the disturbed land classes on each rare or rare-unique soil (defined above), on a state-by-state basis, to estimate the number and location of endangered soils.

Due to the nature of the STATSGO database, and soil mapping in general, there is an inherent uncertainty whether land use affects a given soil. First, because the exact location of soils in a MUID is not known, we have assumed all soils have an equal probability of being affected by the land-use types that apply to a polygon. This assumption can result in significant (but largely impossible to verify) errors in land-use status, particularly (we suspect) for soils of low occurrence. This error will obviously be reduced once future soil databases, which explicitly identify soil locations, become available on a stateor nationwide basis. They are not available now. A second source of error occurs because soil series with small areas are not included in the database. Thus, we likely underestimate the number of rare or endangered soils. Third, the number of soil series (or any other taxonomic class) present in an area increases with the detail at which the area is mapped. Parts of some states have been mapped at a reconnaissance level, and the soil diversity listed (in terms of series) is likely a substantial underestimate. Fourth, STATSGO polygons have a limit of 21 soils, and soils of small extent may not be fully represented in our analysis. Finally, all soil mapping is an inherently complex exercise, involving approximations due to scale limitations of the soil map (commonly $1: 24,000$ ) and some level of bias due to anticipated use of the survey. Soil mapping units used in the development of the STATSGO database may contain significant "inclusions" (that is different soils than the major soil type), and so the actual area of the named soil may be smaller than indicated. While all these inherent uncertainties are undesirable, there is currently no other means of quantitatively approaching the problem for the US. Therefore, all limitations considered, we emphasize that the uncertainty in our analysis is greatly outweighed by the insights that the results provide. Most of the uncertainties in our data err in the conservative direction, such that it is likely our assessment of endangered soils is actually an underestimate.

\section{RESUltS}

\section{Natural Soil Diversity}

The spatial distribution of soil orders reflects the wide gradients of soil age, climate, and biota that systematically change across the nation (Figure 1). There are 11 soil orders, 52 suborders, 233 great groups, 1176 subgroups, 6226 families, and 13,129 series in the 50 states and Puerto Rico in the present STATSGO database (1997 edited version) (Table 1). The recently created $12^{\text {th }}$ order, Gelisols, is present in the US but has not yet been incorporated into STATSGO (additionally, STATSGO data to the series level are not available for Alaska). At the order level, the most abundant (by area) are the Mollisols (soils that generally correlate with grassland vegetation) $\left(207 \times 10^{6} \mathrm{ha}\right)$ and the least abundant are the Oxisols (intensely weathered soils common to stable landforms in tropical environments) $(0.2 \times$ $10^{6} \mathrm{ha}$ ). The relative abundance of soils in the US is not reflective of global patterns, given the nation's predominantly temperate setting.

Hawaii has soil representatives of all 11 orders, while California and Oregon have 10 orders (Table 


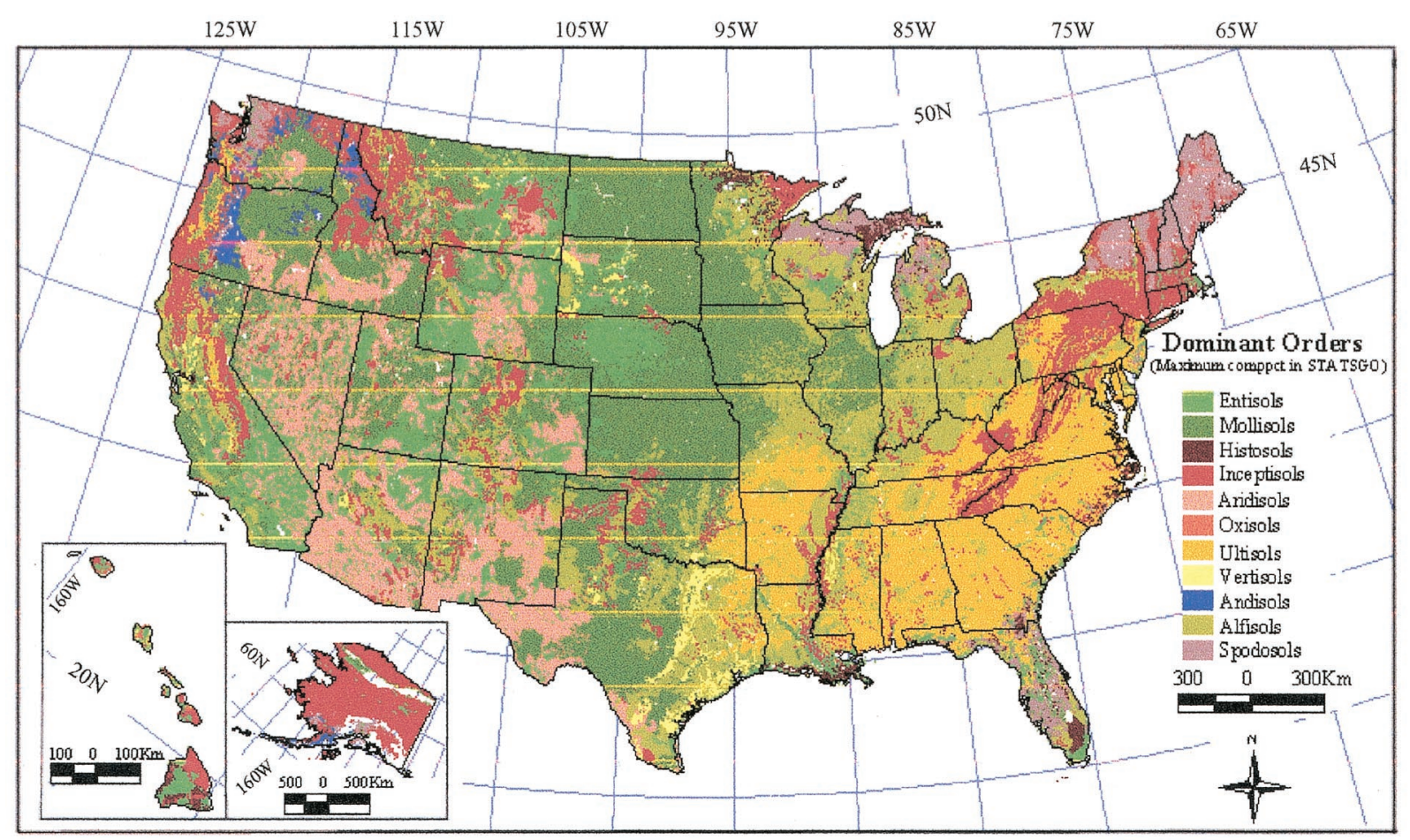

Figure 1. Map of the geographical distribution of soil orders in the US. To prepare the map, the most dominant soil order within a STATSGO mapping unit was used to represent that map unit area.

2). In terms of soil series, California has 1755 series, by far the largest number in the US, followed by Nevada (1354), Idaho (1083), Oregon (1075), and Utah (1006).

\section{Land Use and Natural Soil Diversity}

The USDA Soil Taxonomy is deliberately insensitive to land-use effects on soils (Soil Survey Staff 1999). Agricultural soils are intended to remain in their natural classification except under extreme cases of manipulation (deep ripping, chiseling, construction), in which case they may be grouped into Arents, a special suborder of Entisols ("recent" soils). In practice (K. Arroues personal communication), severely manipulated soils commonly remain in the same classification as their natural counterparts. Therefore, the mapped abundance of soils on soil maps (for example Figure 1) is a reflection of predisturbance distribution and is not indicative of the present undisturbed areas.

Approximately $19 \%$ of the US is under intensive agriculture (Census of Agriculture 1997). Land use in the US is unevenly distributed (Figure 2), with agriculture particularly concentrated in the Midwest, Great Plains, Mississippi Valley, Snake River/ Palouse regions and California's Great Valley. A much smaller percentage of the US is urbanized (approximately 2-3\%) (see for example Nizeyimana and others 2001), but urban growth poses a particular threat to soil resources in the loss of prime agricultural land (Sorenson and others 1997; Imhoff and others 1997; Nizeyimana and others 2001), an important issue, but a topic outside the focus of this article. In most areas, geologically young, level, and highly productive soils are preferentially used for both agriculture and urbanization, a situation that leads to drastic reductions in the area of certain soil types. Figure 2 displays all soil series, regardless of their total extent, that have lost $50 \%$ or more of their area to agriculture or urbanization.

At the order and suborder levels of the US taxonomy, the results of development have resulted in certain soil types being more heavily affected by land use than others. The total undisturbed area of four soil orders has been reduced by more than $20 \%$ : Mollisols (28\%), Histosols (24\%), Vertisols $(24 \%)$, and Alfisols (22\%) (Table 3$)$. At the suborder level, there is also an uneven effect of land use on soils. First, most Mollisol suborders are heavily utilized for agriculture, as is expected due to their inherent high fertility and suitable climate. Second, it is evident that virtually every "aquic" subclass of all orders (soils with at least seasonally high water 
Table 2. Soil Diversity and Rarity, by State and Territory, for the US ${ }^{a}$

\begin{tabular}{|c|c|c|c|c|c|c|c|c|c|}
\hline \multirow[b]{2}{*}{ State } & \multicolumn{5}{|c|}{ Number } & \multirow[b]{2}{*}{$\begin{array}{l}\% \text { of Rare Soils } \\
\text { in State } \\
\text { Endangered }\end{array}$} & \multicolumn{3}{|c|}{ Number/100,000 ha } \\
\hline & Orders & Series $^{\mathrm{b}}$ & $\begin{array}{l}\text { Rare plus } \\
\text { Rare- } \\
\text { Unique } \\
\text { Series }^{\mathrm{c}}\end{array}$ & $\begin{array}{l}\text { Endangered } \\
\text { Soil Series }^{\mathrm{d}}\end{array}$ & $\begin{array}{l}\text { Extinct } \\
\text { soil series }^{d}\end{array}$ & & Series & $\begin{array}{l}\text { Rare plus } \\
\text { Rare- } \\
\text { Unique }\end{array}$ & $\begin{array}{l}\text { Endangered } \\
\text { soil series }\end{array}$ \\
\hline Alabama & 8 & 321 & 19 & 0 & & 0.0 & 2.4 & 0.14 & 0.0 \\
\hline Arizona & 6 & 423 & 27 & 0 & & 0.0 & 1.4 & 0.09 & 0.0 \\
\hline Arkansas & 6 & 261 & 3 & 1 & & 33.3 & 1.9 & 0.02 & 0.0 \\
\hline California & 10 & 1755 & 671 & 104 & 1 & 15.5 & 4.3 & 1.64 & 0.3 \\
\hline Colorado & 8 & 856 & 153 & 0 & & 0.0 & 3.2 & 0.57 & 0.0 \\
\hline Connecticu & 4 & 86 & 8 & 4 & & 50.0 & 6.7 & 0.62 & 0.3 \\
\hline Delaware & 6 & 52 & 0 & 0 & & 0.0 & 9.9 & 0.00 & 0.0 \\
\hline Florida & 7 & 298 & 67 & 9 & 3 & 13.4 & 2.0 & 0.44 & 0.1 \\
\hline Georgia & 7 & 250 & 4 & 0 & & 0.0 & 1.6 & 0.03 & 0.0 \\
\hline Hawaii & 11 & 182 & 159 & 0 & & 0.0 & 11.3 & 9.83 & 0.0 \\
\hline Idaho & 9 & 1083 & 361 & 49 & & 13.6 & 5.0 & 1.67 & 0.2 \\
\hline Illinois & 6 & 358 & 44 & 29 & 6 & 65.9 & 2.5 & 0.30 & 0.2 \\
\hline Indiana & 6 & 365 & 44 & 36 & 2 & 81.8 & 3.9 & 0.47 & 0.4 \\
\hline Iowa & 5 & 262 & 26 & 21 & & 80.8 & 1.8 & 0.18 & 0.1 \\
\hline Kansas & 7 & 370 & 14 & 6 & & 42.9 & 1.7 & 0.07 & 0.0 \\
\hline Kentucky & 6 & 211 & 14 & 0 & & 0.0 & 2.0 & 0.13 & 0.0 \\
\hline Louisiana & 7 & 304 & 41 & 10 & 1 & 24.4 & 2.5 & 0.33 & 0.1 \\
\hline Maine & 4 & 111 & 8 & 0 & & 0.0 & 1.3 & 0.10 & 0.0 \\
\hline Maryland & 7 & 187 & 7 & 0 & & 0.0 & 6.8 & 0.25 & 0.0 \\
\hline Massachu & 5 & 129 & 5 & 0 & & 0.0 & 6.2 & 0.24 & 0.0 \\
\hline Michigan & 6 & 371 & 86 & 10 & & 11.6 & 2.5 & 0.57 & 0.1 \\
\hline Minnesota & 6 & 620 & 122 & 65 & 6 & 53.3 & 2.8 & 0.56 & 0.3 \\
\hline Mississippi & 7 & 220 & 17 & 2 & & 11.8 & 1.8 & 0.14 & 0.0 \\
\hline Missouri & 6 & 365 & 27 & 12 & 4 & 44.4 & 2.0 & 0.15 & 0.1 \\
\hline Montana & 9 & 693 & 188 & 21 & & 11.2 & 1.8 & 0.49 & 0.1 \\
\hline Nebraska & 6 & 268 & 23 & 14 & 2 & 60.9 & 1.3 & 0.12 & 0.1 \\
\hline Nevada & 8 & 1354 & 399 & 1 & & 0.3 & 4.7 & 1.39 & 0.0 \\
\hline \multicolumn{10}{|l|}{ New } \\
\hline Hamp & 4 & 127 & 10 & 0 & & 0.0 & 5.3 & 0.42 & 0.0 \\
\hline \multicolumn{10}{|l|}{ New } \\
\hline Jersey & 7 & 148 & 22 & 2 & & 9.1 & 7.5 & 1.12 & 0.1 \\
\hline \multicolumn{10}{|l|}{ New } \\
\hline Mexico & 7 & 744 & 139 & 0 & & 0.0 & 2.4 & 0.44 & 0.0 \\
\hline New York & 7 & 347 & 37 & 2 & 1 & 5.4 & 2.7 & 0.29 & 0.0 \\
\hline \multicolumn{10}{|l|}{ North } \\
\hline Caro & 6 & 228 & 18 & 0 & & 0.0 & 1.8 & 0.14 & 0.0 \\
\hline \multicolumn{10}{|l|}{ North } \\
\hline Dako & 7 & 272 & 26 & 10 & & 38.5 & 1.5 & 0.14 & 0.1 \\
\hline Ohio & 6 & 339 & 46 & 21 & 2 & 45.7 & 3.2 & 0.43 & 0.2 \\
\hline Oklahoma & 7 & 463 & 46 & 3 & & 6.5 & 2.6 & 0.25 & 0.0 \\
\hline Oregon & 10 & 1075 & 301 & 16 & & 5.3 & 4.3 & 1.20 & 0.1 \\
\hline Pennsylva & 7 & 248 & 20 & 0 & & 0.0 & 2.1 & 0.17 & 0.0 \\
\hline \multicolumn{10}{|l|}{ Puerto } \\
\hline Rico & 9 & 159 & 135 & 0 & & 0.0 & 17.6 & 14.93 & 0.0 \\
\hline \multicolumn{10}{|l|}{ Rhode } \\
\hline Isla & 3 & 45 & 2 & 0 & & 0.0 & 15.9 & 0.71 & 0.0 \\
\hline \multicolumn{10}{|l|}{ South } \\
\hline Caro & 7 & 214 & 13 & 0 & & 0.0 & 2.7 & 0.16 & 0.0 \\
\hline \multicolumn{10}{|l|}{ South } \\
\hline Dakt & 6 & 563 & 61 & 18 & & 29.5 & 2.8 & 0.31 & 0.1 \\
\hline
\end{tabular}


Table 2. (Continued)

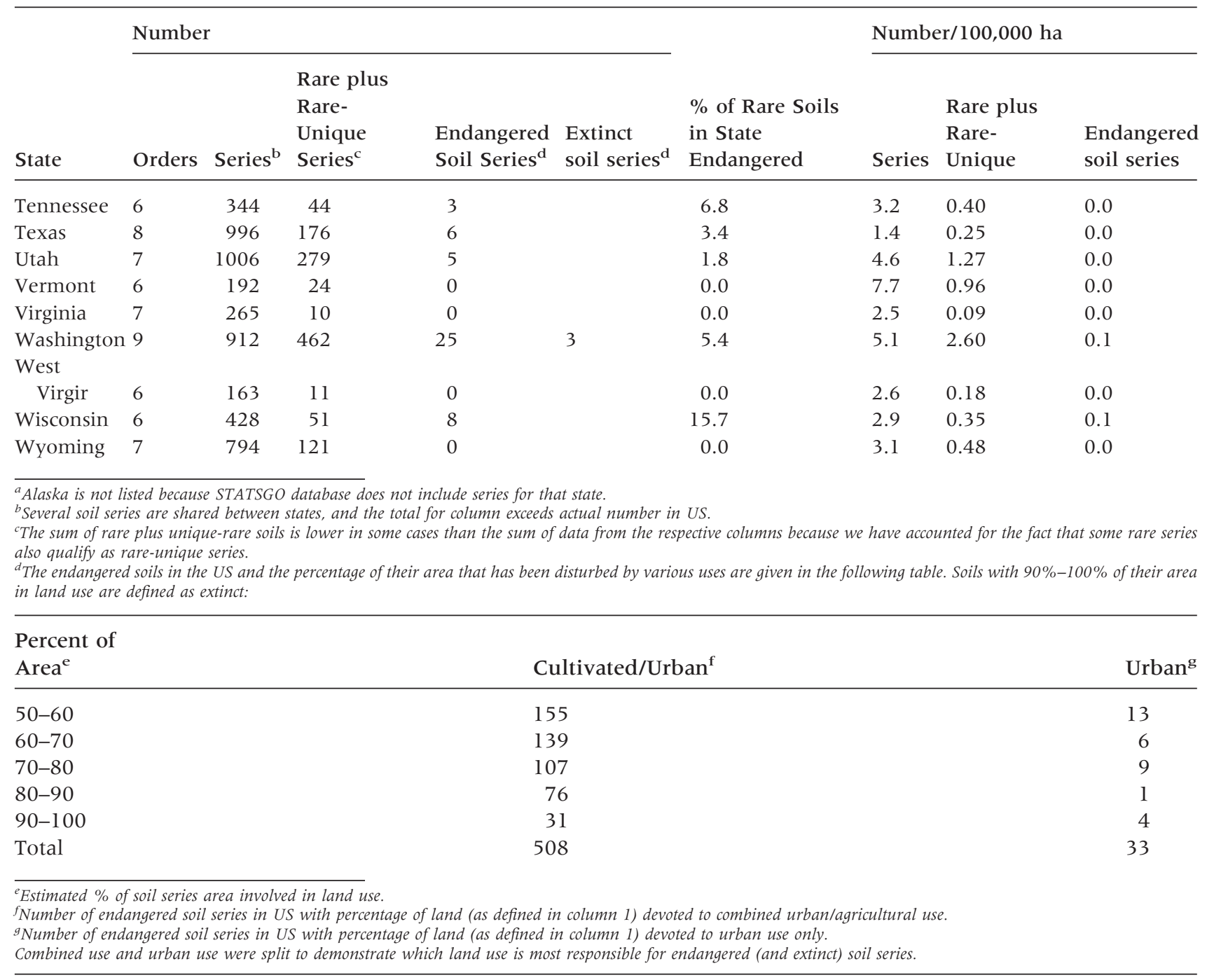

tables and features indicative of saturation) are preferentially utilized for agriculture.

Rare, Unique, and Endangered Soils in the US

We found 4540 rare or rare-unique soil series (Table 2), $35 \%$ of the total in the US. California has the largest number of unique soil series (1113), followed by Washington (712), Texas (630), Nevada (594), Oregon (573), and Idaho (547). The overall diversity and "soil endemism" within California is understandable in terms of the wide range and unique combinations of climate, flora, and geology within the state. It is likely these same combinations of factors have contributed to the biological diversity and high endemism of the region (Myers and others 2000; Cincotta and others 2000). California also leads the nation in terms of rare or rare-unique soil series (671), followed by Washington (462), Nevada (399), Idaho (361), and Oregon (301). In terms of the "density" of rare or unique soils (soils/area), the territory of Puerto Rico leads the states/territories (approximately 15 unique series/100,000 ha), followed by Hawaii (10), Washington (3), Idaho (2), and California (2).

There are 508 endangered soils in the US with a total area of $1,874,092$ ha, about $0.3 \%$ of the US land area (Figure 3). With respect to endangered soils, California leads the nation with 104 endangered soil series, followed by Minnesota (65), Idaho (49), Indiana (36), and Illinois (29). In terms of endangered soil density, Indiana leads this category (0.4 series/100,000 ha), followed by Connecticut (0.3), Minnesota (0.3), California (0.3), and Idaho $(0.2)$. In the US, there are presently 31 soils that may be considered "extinct" (90-100\% land con- 


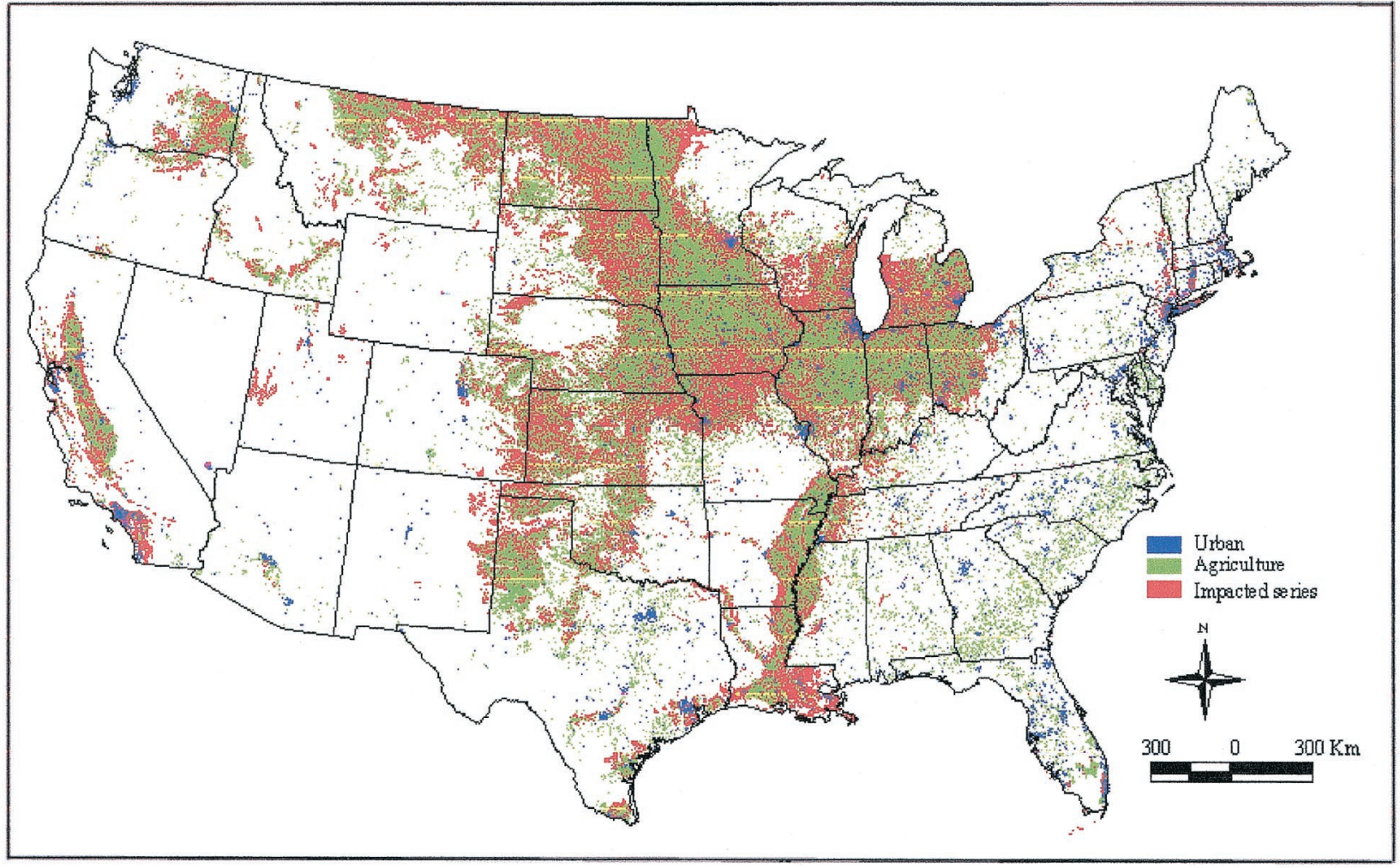

Figure 2. Map illustrating the distribution of agriculture and urban land use in the US (from NLCD data) and the resulting distribution of soil series that have lost $50 \%$ or more of their original area to land use.

version) (Table 2): 27 converted to agriculture and 4 to urban uses.

Six states have more than $50 \%$ of their rare soil series in an endangered state, with Indiana leading the group at $82 \%$, followed by Iowa $(81 \%)$, Illiniois $(66 \%)$, Nebraska (61\%), Minnesota (53\%), and Connecticut (50\%). In general, the corn and wheat belt states (plus Connecticut) comprise a group of states where more than $25 \%$ of their rare soils are endangered. California, in contrast, has only 15\% of its rare soils in an endangered state. A large group of states have no endangered soils.

The data illustrated in Figure 3 indicate that the "hotspots" of soil in danger of elimination reside in the agricultural heartland of the country, a land-use conflict that has been recently discussed in terms of its effect on biological diversity (Margules and Gaston 1994; and Huston 1994). We find that the prevalence of endangered soils increases with the annual value of agricultural products produced by the state (Figure 4), a relationship noted by Dobson and others (1997) for endangered plants. Considerable variability exists in this relationship, but the most notable exceptions are the states of California and Texas, both with high production values but relatively low percentage of rare soils endangered.
In California, agriculture is concentrated primarily in the large structural basins of the Great Central, Salinas, and Imperial Valleys-geographically restricted areas of high-intensity agriculture and high-value products, characteristics which reduce the impact on remaining portions of the state. Connecticut is a second type of outlier (a relatively high percentage of endangered soils coupled with a low agricultural output), possibly due to the state's relatively small land area and the combined impact of agriculture and urbanization in its lowland corridor (Figure 3). Regardless of the exceptions, it is apparent that agricultural output and endangered soils are positively correlated. Although agriculture is the main mechanism reducing soil diversity, urbanization (despite its low total land area) is responsible for nearly 33 endangered soils nationally (footnote of Table 2).

\section{Discussion}

The US has enormous natural soil diversity (Figure 1 ), yet our investigation indicates that these data are not representative of the extant, or undisturbed, soil resources. We argue that a change in land use results in profound changes in one or more soil 
Table 3. Percentage of Total Soil Orders and Suborders Affected by Development in the US

\begin{tabular}{|c|c|c|c|c|c|c|c|}
\hline \multirow[b]{2}{*}{ Order } & \multicolumn{3}{|l|}{$\%$} & \multirow[b]{2}{*}{ Suborder } & \multicolumn{3}{|l|}{$\%$} \\
\hline & Urban & Agriculture & Total & & Urban & Agriculture & Total \\
\hline \multirow[t]{5}{*}{ Alfisols } & 2.85 & 19.37 & 22.22 & Aqualfs & 4.13 & 28.62 & 32.75 \\
\hline & & & & Boralfs & 0.48 & 10.50 & 10.98 \\
\hline & & & & Udalfs & 4.02 & 24.84 & 28.86 \\
\hline & & & & Ustalfs & 1.07 & 16.88 & 17.95 \\
\hline & & & & Xeralfs & 3.27 & 8.00 & 11.27 \\
\hline \multirow[t]{7}{*}{ Andisols } & 0.35 & 1.96 & 2.30 & Andepts & 0.36 & 0.49 & 0.85 \\
\hline & & & & Aquands & 0.52 & 11.18 & 11.70 \\
\hline & & & & Cryands & 0.21 & 0.75 & 0.95 \\
\hline & & & & Torrands & 1.30 & 0.65 & 1.94 \\
\hline & & & & Udands & 0.53 & 0.08 & 0.61 \\
\hline & & & & Vitrands & 0.16 & 1.15 & 1.31 \\
\hline & & & & Xerands & 0.32 & 1.06 & 1.38 \\
\hline \multirow[t]{2}{*}{ Aridisols } & 0.61 & 5.46 & 6.07 & Argids & 0.61 & 3.94 & 4.55 \\
\hline & & & & Orthids & 0.63 & 5.12 & 5.75 \\
\hline \multirow[t]{5}{*}{ Entisols } & 2.38 & 17.34 & 19.72 & Aquents & 3.89 & 22.24 & 26.13 \\
\hline & & & & Arents & 9.19 & 15.81 & 25.00 \\
\hline & & & & Fluvents & 1.94 & 21.24 & 23.18 \\
\hline & & & & Orthents & 1.59 & 13.27 & 14.86 \\
\hline & & & & Psamments & 3.49 & 12.79 & 16.28 \\
\hline \multirow[t]{4}{*}{ Histosols } & 3.51 & 20.69 & 24.20 & Fibrists & 0.54 & 2.45 & 3.00 \\
\hline & & & & Folists & 0.28 & 0.35 & 0.63 \\
\hline & & & & Hemists & 2.36 & 8.13 & 10.49 \\
\hline & & & & Saprists & 3.60 & 22.44 & 26.05 \\
\hline \multirow[t]{4}{*}{ Inceptisols } & 2.55 & 12.27 & 14.82 & Aquepts & 3.57 & 17.70 & 21.26 \\
\hline & & & & Ochrepts & 2.50 & 10.52 & 13.03 \\
\hline & & & & Tropepts & 2.28 & 0.21 & 2.49 \\
\hline & & & & Umbrepts & 1.32 & 1.02 & 2.34 \\
\hline \multirow[t]{7}{*}{ Mollisols } & 1.81 & 25.69 & 27.50 & Albolls & 1.16 & 54.29 & 55.45 \\
\hline & & & & Aquolls & 2.99 & 44.95 & 47.94 \\
\hline & & & & Borolls & 0.38 & 23.61 & 23.99 \\
\hline & & & & Rendolls & 1.39 & 4.91 & 6.29 \\
\hline & & & & Udolls & 3.35 & 41.92 & 45.28 \\
\hline & & & & Ustolls & 1.14 & 23.52 & 24.65 \\
\hline & & & & Xerolls & 1.90 & 7.86 & 9.76 \\
\hline \multirow[t]{4}{*}{ Spodosols } & 3.99 & 8.60 & 12.58 & Aquods & 5.98 & 12.43 & 18.42 \\
\hline & & & & Cryods & 0.29 & 0.18 & 0.46 \\
\hline & & & & Humods & 0.88 & 1.57 & 2.45 \\
\hline & & & & Orthods & 2.67 & 5.97 & 8.64 \\
\hline \multirow[t]{5}{*}{ Ultisols } & 3.05 & 8.63 & 11.68 & Aquults & 3.63 & 15.93 & 19.56 \\
\hline & & & & Humults & 0.92 & 1.01 & 1.93 \\
\hline & & & & Udults & 3.15 & 9.06 & 12.21 \\
\hline & & & & Ustults & 3.00 & 2.23 & 5.23 \\
\hline & & & & Xerults & 1.30 & 1.80 & 3.10 \\
\hline \multirow[t]{6}{*}{ Vertisols } & 2.35 & 21.31 & 23.67 & Aquerts & 1.77 & 49.12 & 50.89 \\
\hline & & & & Torrerts & 0.38 & 3.11 & 3.49 \\
\hline & & & & Uderts & 5.65 & 18.16 & 23.81 \\
\hline & & & & Usterts & 1.67 & 25.62 & 27.29 \\
\hline & & & & & & & 17.95 \\
\hline & & & & Xererts & 5.73 & 12.22 & \\
\hline
\end{tabular}

properties and in a soil's biogeochemical functioning, to the degree that the soil is no longer representative of its undisturbed counterpart. Again, us- ing a biological analogy, cultivated soils might be viewed as domesticated versions of their natural counterparts, with widely differing properties and 


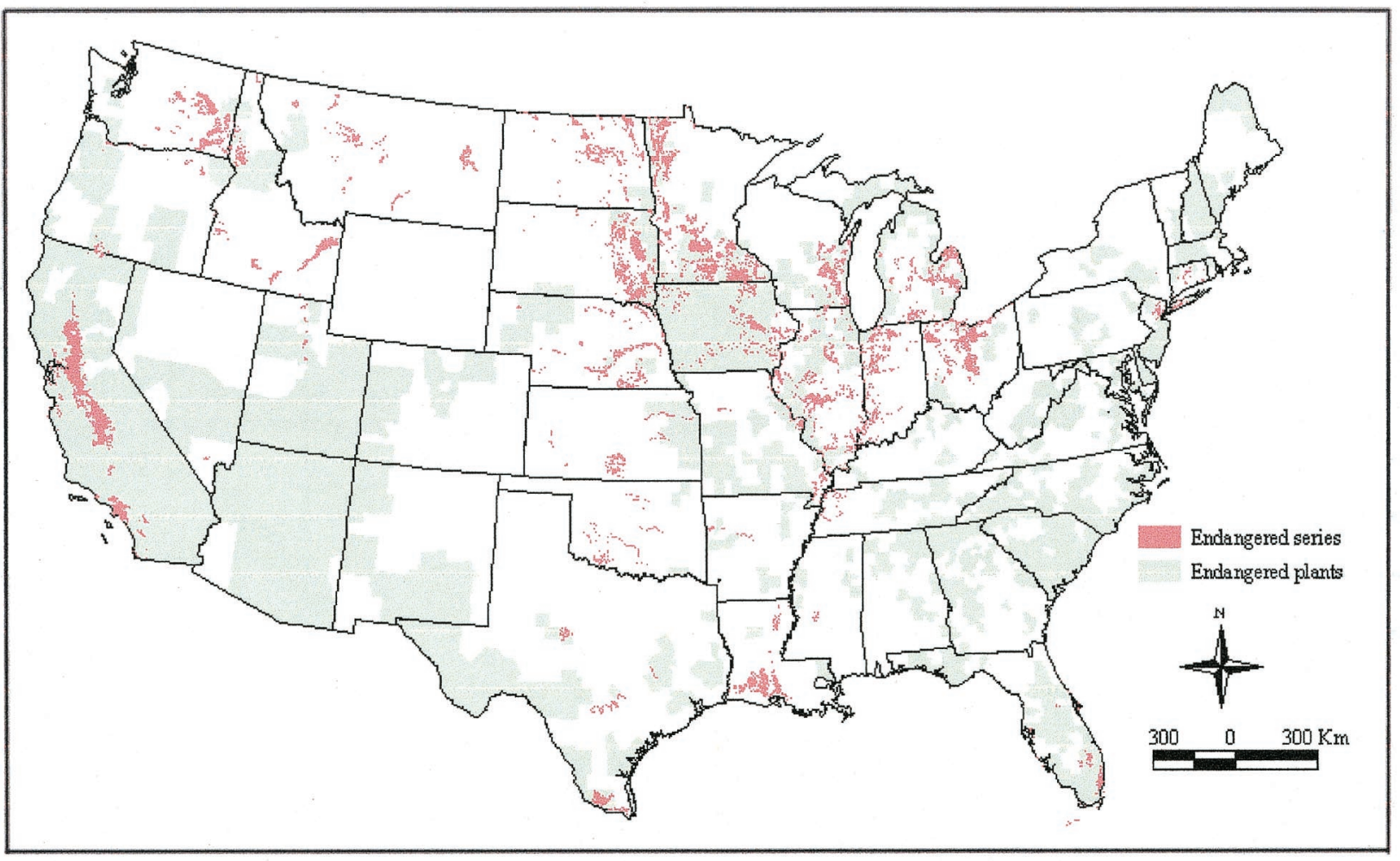

Figure 3. Map illustrating the distribution of endangered plants and endangered soils (see text for definition) in the US. Data for plants are from Dobson and others (1997).

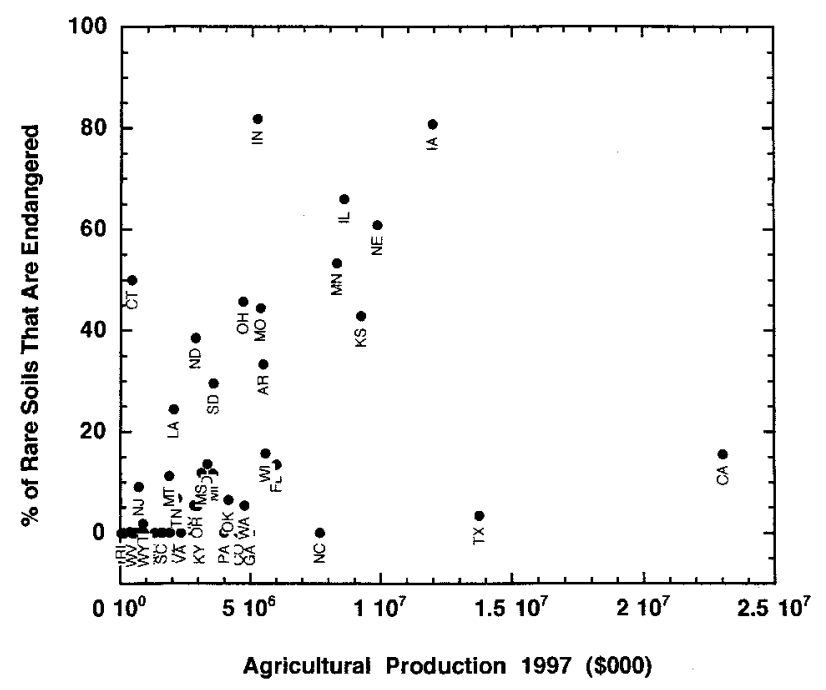

Figure 4. The correlation between the percentage of a state's rare soils that are endangered (data from Table) and its total agricultural production (\$) in 1997 (Census of Agriculture 1997).

functions. As we discuss below, these changes and others are important for an array of scientific and societal reasons.

\section{Why Natural Soil Diversity Matters}

Successful arguments for scientifically based conservation/preservation plans rely on both what we know and what we don't know about a habitat's values and services (Noss and others 1997). In terms of values that are cited to warrant the preservation of biodiversity, Ehrlich and Wilson (1991) identified aesthetic, ethical, economic, and ecosystem services as key areas of consideration and importance to human society. These reasons and more, including scientific and educational benefits, have a bearing on soil preservation efforts and their value to society. However, it is important to be clear that there is a dearth of information on why natural soils as a whole, or specific natural soil series individually, are quantitatively important to society. The primary reason for this is not due to an inherently low value of natural soils, but that these analyses have not been an imperative in a field (soil science and agronomy) whose driving forces have focused on the effective and efficient conversion of natural landscapes to farmland. Clearly, this focus will continue well into this century as we enter what has been termed "the final period of rapidly 
expanding, global human environmental impacts," particularly in the area of agricultural expansion to meet food demands (Tilman and others 2002). However, a fundamental institutional shift in these sciences is required to quantify and derive societal value from remaining natural soils and ecosystems and to provide the scientific basis to argue for their preservation.

Daily (1997) suggests that there are three ways in which science may contribute to a public understanding of biodiversity and ecosystem-related values: (a) establish standard metrics and systematic monitoring of the magnitude and rates of human change of ecosystems, (b) use the metrics to project the way in which change affects the functioning of ecosystems, and (c) translate the change into meaningful social terms of human health and economic well-being. In this article, which addresses the issue of soil diversity, we have thus far focused primarily on the first goal. Here, using a few examples, we attempt to provide a glimpse into the value of the "services" of natural soils as a population, for there are simply too few data to discuss specific soil types individually.

Daily (1997) lists the production of goods and services as a key ecosystem value. The economic value of soils has centered on agricultural lands. For example, the total value of US agricultural production (much derived from cultivated lands) in 1997 was $\$ 197$ billion (Census of Agriculture 1997). The monetary value that can be derived from products from uncultivated soils (beyond grazing/timber) has not been fully examined. One potential source of income may lie in "bio-prospecting" for medicinal and industrial purposes. Antibiotics, such as streptomycin (Yaalon 2000), continue (for example, see Fielfer and others 2000) to be derived from soil microorganisms. However, there is a fundamental lack of knowledge on the geographical distribution of soil microbial diversity. Though it is commonly argued that global dispersal of microorganisms is "rarely (if ever) restricted by geographical barriers" (Findlay 2002), detailed genetic analyses of widely dispersed soils reveals a different pattern, one of "strong endemicity suggesting that heterotrophic soil bacteria are not globally mixed" (Cho and Tiedje 2000). The effect of land use on microbial biodiversity, using modern genetic tools, is also a poorly studied area. However, a recent study examining the conversion of a tropical rainforest to pasture in Hawaii showed that there was a $49 \%$ change in the microbial populations as a result of the land-use change (Nüsslein and Tiedje 1999). Given the uncertainty about below- ground soil microbial diversity (Adams and Wall 2000), these large reported changes warrant further research and ecological consideration but seem to justify concern over the effect of cultivation on below-ground genetic resources.

It is well recognized that undisturbed soils, and ecosystems, provide societal benefits from "regenerative and stabilizing processes" (Daily 1997; Daily and others 1997) in the form of water and elemental cycling on a global scale, regulating the climate, atmosphere, and hydrosphere conditions that allowed human society to expand so successfully during the Holocene. Tilman and others (2002) note that these services are "difficult to quantify and have rarely been priced." The magnitude of these services is sometimes most appreciated following their loss (Daily and others 2000). For example, in terms of C cycling, the cultivation of present agricultural lands worldwide has released approximately 55-70 Gt of $\mathrm{C}$ as $\mathrm{CO}_{2}$ (Paustian and others 1997; Amundson 2001), equivalent to approximately 12 years of present day fossil fuel burning. In terms of the $\mathrm{N}$ cycle, the mobilization of $\mathrm{N}$ from agricultural lands may be on the order of $4800 \mathrm{Tg} \mathrm{N}\left(10^{12} / \mathrm{g}\right)$ (assuming $\mathrm{N}$ release during soil organic matter decomposition proportional to $\mathrm{C}$ ). Currently, land clearing and drainage of wetlands may be releasing $30 \mathrm{Tg} / \mathrm{y}$ (Vitousek and others 1997b). While the "value" of pristine global soil conditions is possibly debatable, the costs (monetary and human health) associated with its disruption in terms of climate change, water quality, and disease is a focus of considerable international attention and analysis (IPCC 2001).

Two attributes of soil diversity that may be compelling to many are (a) the linkage between rare soils and rare plants and (b) the linkage between endangered soils and plants, relationships that intimately link soil and biodiversity preservation arguments and planning. As an example of the relationship of rare soils to plants, we discuss the annual grasslands of eastern Merced County, California, a region that is an integral part of the California Floristic Province, one of the top 25 biodiversity hotspots on Earth (Cincotta and others 2000; Myers and others 2000). The region near the city of Merced is a complex mosaic of river/steam terraces or floodplains, that range in age from $10^{2}$ to $10^{6}$ years (Marchand and Allwardt 1981), with extensive areas of vernal pools. A sizable number of endemic species form in these pools (Volmar 2002). There is a systematic change in pool frequency and soil chemistry (Brenner and others 2001) with time that creates an edaphic gradient that is a major factor in influencing the plant species composition on a regional scale (Holland and Dains 1990). Holland and Dains (1990) found distinctive edaphic 
preferences of the regional flora related to soil age and parent material and concluded that "attempts to mitigate the effects of proposed developments by transplanting whole vernal pool ecosystems to off site locations can not hope to succeed by use of blanket prescriptions to mimic soil profile conditions at the target site." Because of the plant preferences for specific soils near Merced, and the fact that the Merced area has the last remaining tracts of undisturbed soils peculiar to the oldest landforms, the initial science panel input into the Natural Community Conservation Plan (NCCP) and Habitat Conservation Plan (HCP) for the area emphasizes the need to establish a reserve design that explicitly includes a diversity of undisturbed soils (Noss and others unpublished). More generally, the relation between edaphic factors and biological diversity has been discussed in greater lengths elsewhere (Huston 1993; Margules and others 1994; Huston 1994), emphasizing both the linkages and the complexities.

Both plants and soils become endangered as a result of land use. Figure 3 illustrates the location of endangered soil series and the counties containing endangered plants in the US. The plants and soils clearly exhibit geographical differences, but also some similarities. Counties with endangered plants cover wide areas that contain few or no endangered soils. A major reason for this is that officially listed endangered plants are reportedly caused by grazing, logging, and other land uses (Flather and others 1994) which we have not deemed as affecting soil diversity. If our criteria for minimal disturbance that changes inherent natural soil processes had not been so conservative, the areas of endangered soils in the US would have certainly expanded and had greater overlap with the plants. However, even with our restricted approach, it is clear that both endangered plants (Flather and others 1994; Dobson and others 1997) and soils (Figure 2) occur in heavily cultivated and urbanized areas. We note that Dobson and others (1997) reported that "agricultural activity is the key variable for plants (endangerment) $\left(r^{2}=0.61, P<0.01\right)$," a relationship with which the soil data are consistent.

While the discussion above gives a few scholarly and scientific reasons justifying the preservation of natural soils, it is equally valid to argue that a diversity of natural soils be maintained because we lack a scientific understanding of their full values and functions. This justification, called the "precautionary principle" in habitat conservation plans (Sharder-Frechette and McCoy 1993; Noss and others 1997) shifts the burden of proof for preservation from conservationists to developers in order to reduce the possibility that a "Type II" error occurs (acceptance of conclusion that no effect from land use occurs when one actually exists). The concern over Type II errors is argued to be particularly relevant to applied sciences (medicine, environmental engineering, and conservation biology) where such an error causes irreversible damage to the patient, ecosystem, or soil (Noss and others 1997). "Nature is full of surprises" (Noss and others 1997), and, in terms of natural soil types, numerous surprises and benefits will undoubtedly reveal themselves in the future. However, our present ignorance should not be an impediment to arguing that landscapes warrant preservation. The conservation of diverse soilscapes should proceed simultaneously with scientific research that fully explores their qualities, values, and functioning.

\section{ConClusions}

In less than two centuries, the landscape of the US has been transformed to a degree that would astound our 19th century predecessors. The change is not complete. Population growth and the on-going redistribution of the US population pose new and challenging issues to preservation efforts of all types. Soils, viewed during this expansion as an economic commodity, have in many cases become rare to the degree that we and others (Ibáñez and others 1995, 1998) suggest they become part of formal biodiversity planning.

This initial quantitative analysis of land-use effects on soil diversity raises many questions and opportunities for future research. Some key directions include:

1. Use of improved soil databases: Our analysis, made with the generalized STATSGO database, contains numerous uncertainties as discussed in the text. In the near future, the USDA-NRCS will likely release the SSURGO (Soil Survey Geographical) database, which will be a digital compilation of detailed 1:24,000 soil surveys. This dataset will greatly refine both the number and location of heavily impacted soils in the US. However, the general method of our initial query using STATSGO will apply to the use of this improved database.

2. Examination of soil distribution by ecological rather than political boundaries: As a result of our own interest in soil distribution by state, and for our study to parallel national analyses of endangered flora and faunas (Dobson and others 1997), we have used political boundaries to quantify soil diversity. The STATGO/SSURGO databases offer the opportunity to examine soil distribution 
along general ecological boundaries-Major Land Resources Areas (MRLAs). Future work, which we are already initiating (Guo and others 2003), should further explore soil diversity by ecological region.

3. Monitor changes in soil diversity in response to changing land-use: Here we provided a snapshot of a land-use/soil overlay based on 1990s land-use patterns in the US. As Daily (1997) notes, it will be important to periodically monitor changes of agriculture and urbanization in the future in order to quantify the rate of soil change.

4. Extend the method to global scales: While the US is certain to experience land-use changes in the future, it might be argued that the present areas of intensive agricultural expansion are the tropics and subtropics. Unfortunately, geographically referenced soil data are unavailable for the globe, highlighting the unique value that the STATSGO database provides for the US.

5. Establish the societal value of undisturbed soils: Following the lead of ecologists (Daily and others 1997, 2000), other scientists and economists must begin to assign value to undisturbed soilscapes and make the value known to the general public. This must also include the value of present farmland in rapidly urbanizing areas, since the loss of this land increases the pressure to agriculturally develop native landscapes elsewhere.

6. Focus conservation efforts in soil diversity "hotspots": Our analysis clearly shows that certain areasthe Midwestern states for example-have been severely impacted by human activity. Efforts to locate and maintain tracts of undisturbed soils and ecosystems there deserve immediate and special attention.

Soils are integral components of terrestrial ecosystems, providing global-scale services in elemental cycling, water purification, genetic diversity, and more (Daily and others 1997). The importance of soil as an agricultural resource has been successfully cast to capture the public imagination and support (Sorenson and others 1997). The key now is to extend these arguments and to direct attention to the Earth's remaining natural soils. We conclude by recognizing that even these "pristine" sites commonly support an array of invasive species and experience atmospheric $\mathrm{N}$ inputs, fire regimes, and now (and into the future) climatic conditions different than in preindustrial society (for example, Vitousek and others 1997a). At this stage in human history, simply minimizing the human footprint on these regions of the landscape constitutes a modest environmental obligation to, and inheritance for, future generations.

\section{ACKNOWLED GMENTS}

We thank Kit Paris and Eric Vinson of the NRCS in California for assistance and advice on the STATSGO database. Stephen Howard at the USGS EROS Data Center provided assistance in describing the NLCD data structure. Mu Lan provided technical assistance, and Cristina Castanha, Stephanie Ewing, and Kyungsoo Yoo provided comments on an earlier draft of the paper. The research was supported by the Kearney Foundation of Soil Science.

\section{REFERENCES}

Adams GA, Wall DH. 2000. Biodiversity above and below the surface of soils and sediments: linkages and implications for global change. Bioscience 50:1043-8.

Amundson R. 1998. Do soils need our protection? Geotimes March: 16-20.

Amundson R. 2000. Are Soils Endangered? In: Schneiderman J, editor. The Earth Around Us, Maintaining a Livable Planet. New York: WH Freeman. p 144-53.

Amundson R. 2001. The carbon budget in soils. Annu Rev Earth Planet Sci 29:535-62.

Amundson R, Jenny H. 1997. On a state factor model of ecosystems. Bioscience 47:536-43.

Brenner DL, Amundson R, Baisden WT, Kendall C, Harden J. 2001. Soil $\mathrm{N}$ and ${ }^{15} \mathrm{~N}$ variation with time in a California annual grassland ecosystem. Geochim Cosmochim Acta 65:4171-86.

Census of Agriculture. 1997: http://www.census.gov/econ/ www/ag0100.html.

Cho J-C, Tiedje JM. 2000. Biogeography and degree of endemicity of fluorescent Pseudomonas strains in soil. Appl Envir Microbiol 66:5448-56.

Cincotta RP, Wisnewski J, Engelman R. 2000. Human population in the biodiversity hotspots. Nature 404:990-2.

Daily GC. 1997. Developing a scientific basis for managing Earth's life support systems. Conserv Ecol 3:14. [online] URL: http://www.consecol.org/vol3/iss2/art14.

Daily GC, Matson PA, Vitousek PM. 1997. Ecosystem services supplied by soil. In: Daily GC, editor. Natures Services. Washington, DC: Island Press. p 113-32.

Daily GC, Söderqvist T, Aniyar S, Arrow K, Dasgupta P, Ehrlich PR, Folke C, Jansson A, Jansson B-O, Kautsky N, Levin S, Lubchenco J, Mäler K-G, Simpson D, Starrett D, Tilman D, Walker B. 2000. The value of nature and the nature of value. Science 289:395-96.

Dobson AP, Rodriguez JP, Roberts WM, Wilcove DS. 1997. Geographic distribution of endangered species in the United States. Science 275:550-3.

Ehrlich PR, Wilson EO. 1991. Biodiversity studies: science and policy. Science 2:758-62.

Finlay BJ. 2002. Global dispersal of free-living microbial eukaryote species. Science 296:1061-63.

Flather CH, Joyce LA, Bloomgarden CA. 1994. Species endangerment in the United States. RM-241. General Technical Report, Rocky Mountain Forest and Range Experimental Station. Ft. Collins, CO: US Department of Agriculture. 
Guo Y, Amundson R, Gong P, Ahrens R (2003) Taxonomic structure, distribution, and abundance of the soils in the United States (in review).

Holland RF, Dains VI. 1990. The edaphic factor in vernal pool vegetation. In: Ikeda DH, Schlising RA, editors. Vernal Pool Plants: Their Habitat and Biology. Studies from the Herbarium, Number 8. Chico, CA: CSU. p 31-48.

Huston M. 1993. Biological diversity, soils, and economics. Science 262:1676-80.

Huston M. 1994. Biological diversity and agriculture. Science 265:458-59.

Ibáñez JJ, De-Alba S, Bermúdez FF, García-Álvarez A. 1995. Pedodiversity: concepts and measures. Catena 24:215-32.

Ibáñez JJ, De-Alba S, Lobo A, Zucarello V. 1998. Pedodiversity and global soil patterns at coarse scales. Geoderma 83:171-92.

Imhoff ML, Lawrence WT, Elvidge CD, Paul T, Levine E, Privalsky MV, Brown V. 1997. Using nighttime DMSP/OLS images of city lights for estimating the impacts of urban land use on soil resources in the United States. Remote Sens Environ 59: 105-17.

IPCC. 2000. Land Use, Land-use Change, and Forestry. Summary for Policy Makers. Intergovernmental Panel on Climate Change, World Meteorological Organization/United Nations Environment Programme.

Jenny H. 1941. Factors of Soil Formation. New York: McGrawHill.

Marchand DE, Allwardt A. 1981. Later Cenozoic stratigraphic units in northeastern San Joaquin Valley, California. US Geological Survey Bulletin 170. Washington, DC: US G P U.

Margules CR, Gaston KJ. 1994. Biological diversity and agriculture. Science 265:457.

Myers N, Mittermier RA, Mittermeier CG, da Fonseca GAB, Kent J. 2000. Biodiversity hotspots for conservation priorities. Nature 403:853-8.

Nizeyimana EL, Peterson GW, Imhoff ML, Sinclair HR Jr., Waltman SW, Reed- Margetan DS, Levine ER, Russo JM. 2001. Assessing the impact of land conversion to urban use on soils with different productivity levels in the USA. Soil Sci Soc Am J 65:391-402.
Noss R, O'Connell MA, Murphy DD. 1997. The Science of Conservation Planning. Habitat Conservation Under the Endangered Species Act. Washington, DC: Island Press.

Nüsslein K, Tiedje JM. 1999. Soil bacterial community shift correlated with change from forest to pasture vegetation in a tropical soil. Appl Environ Microbiol 65:3622-6.

Paustian K, Andrèn O, Janzen HH, Lal R, Smith P, Tian G, Tiessen H, Van Noordwijk M, Woomer PL. 1997. Agricultural soils as a sinck to mitigate $\mathrm{CO}_{2}$ emissions. Soil Use Manage 13:230-244.

Pfeifer BA, Admiraal SJ, Gramajo H, Cane DE, Khosla C. 2000. Biosynthesis of complex polyketides in a metabolically engineered strain of E. coli. Science 291:1790-2.

Shrader-Frechette KS, McCoy ED. 1993. Method in Ecology: Strategies for Conservation. Cambridge, UK: Cambridge University Press.

Soil Survey Staff. 1999. Soil Taxonomy. A Basic System of Soil Classification for Making and Interpreting Soil Surveys. Agric. Handbk. 436. US Department of Agriculture., Nat Res Cons Serv. Washington, DC: US GPO.

Sorenson AA, Greene RP, Russ K. 1997. Farming on the edge. DeKalb, IL: American Farmland Trust, Center for Agricultural Development, Northern Illinois University.

Thoreau HD. 2001. Collected Essay and Poems. Library of America.

Tilman D, Cassman KG, Matson PA, Naylor R, Polasky. 2002 Agricultural sustainability and intensive production practices Nature 418:671-7.

Vitousek PM, Mooney HA, Lubchenco J, Mellilo JM. 1997a. Human domination of earth's ecosystems. Science 277:494-9.

Vitousek PM, Aber JD, Howarth RW, Likens GE, Matson PA, Schindler DW, Schlesinger WH, Tilman DG. 1997b. Human alterations of the global nitrogen cycle: sources and consequences. Ecol Appl 7:737-50.

Vollmar JE. 2002. Wildlife and Rare Plant Ecology of Eastern Merced County's Vernal Pool Grasslands. Berkeley, CA: Vollmar Consulting.

Yaalon D. 2000. Down to earth. Why soil-and soil sciencematters. Nature 407:301. 